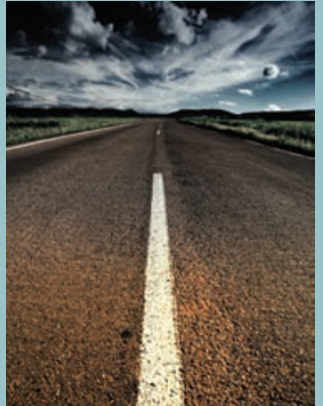

Cover design by Karen Moore

Nature Reports Climate Change

EDITORIAL OFFICE

Editor: Olive Heffernan

Copy Editor: Anna Barnett

Production Editor: Alexandra Hardy

Art Editor: Karen Moore

Web Production Editor: Manpreet Mankoo

MANAGEMENT OFFICE

Managing Director: Steven Inchcoombe

Publishing Director: David Swinbanks

Publisher: Jason Wilde

Associate Publisher: Emma Green

Editor-in-Chief, Nature Publications: Philip Campbell

Marketing Manager: Louise Porter

Managing Production Editor: Donald McDonald

Senior Production Editor: Derna Simpson

Senior Copy Editor: Jane Morris

Advertising Manager, Physical Sciences: Simon Allardice

The Macmillan Building, 4 Crinan St

London N1 9XW, UK

Tel: +44 (0) 2078334000

e-mail: nature@nature.com

VISIT NATURE REPORTS

CLIMATE CHANGE ONLINE

World Wide Web

http://www.nature.com/reports/climatechange

SUBSCRIPTIONS AND CUSTOMER SERVICES

For UK/Europe (excluding Japan):

Nature Publishing Group, Subscriptions, Brunel Road,

Basingstoke, Hants, RG21 6XS, UK.

Tel: +44 (0) 1256329242 .

Subscriptions and customer services for

Americas - including Canada, Latin America and the

Caribbean: Nature Publishing Group,

Subscription Department, PO Box 5161, Brentwood,

TN 37024-5161.

Tel: (800) 5242688 (US) or 6158505315

(outside the US).

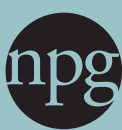

nature publishing group

nature REPORTS climate change

the news behind the science, the science behind the news

\section{CONSTRUCTIVE COMMUNICATION}

The past two months have been an unnerving time for the international climate community. Once seen as one of the most esteemed scientific organizations in the world, the Intergovernmental Panel on Climate Change has, of late, suffered some serious blows to its reputation.

The first of these - dubbed 'Climategate' — saw thousands of emails obtained illegally from the University of East Anglia in the United Kingdom and posted on the Internet. Carefully timed ahead of international climate policy negotiations, the emails showed apparent attempts by a handful of IPCC climatologists to withhold data from climate deniers and to exclude contentious information from the panel's report. Unsurprisingly, this cast doubt on the credibility of the UN body.

Now, the process by which the IPCC assesses climate science has again been called into question. Over the past two weeks, the panel has admitted that a key statistic quoted in its 2007 report - that Himalayan glaciers could disappear by 2035 - was in error, and its source of dubious origin. Hard on the heels of 'Glaciergate' are fresh claims that the same report oversold the link between increasing natural disasters and human-induced warming.

None of these unfortunate events calls into question the evidence that warming is unequivocal and that human activity is the primary cause. But they undoubtedly create confusion among the public and, in this regard, their timing could not be worse. The UN negotiations in December failed to deliver an agreement that would prevent dangerous climate change, and the world now lacks a unified vision of the way forward for climate policy (see page 15). The passage of US domestic legislation also hangs in the balance.

To some extent, the end of the IPCC's exaltation was inevitable. Any organization or individual that is placed on a pedestal will eventually come a cropper. That hard lesson is being learnt as much by the Nobel prizewinning US president as by the Nobel prize-winning IPCC. But there are also more sobering lessons for scientists in all of this. Withholding information from those who question your views or scientific rationale, as was the case in Climategate, does little to instil public trust. The same holds true of responding defensively. When initially confronted with independent evidence on the melting of Himalayan glaciers, IPCC head Rajendra Pachauri retorted that it was "voodoo science".

For the IPCC, the challenge is clear. Faced with political inertia and denialism, they must communicate their results clearly and their message constructively. The 2007 report — and the Summary for Policymakers in particular - represented a giant leap forward for science communication. For the next report, due out in 2013, the challenge will be greater still. In trying to understand the climate system more fully, scientists could reveal greater uncertainty about the range of possible climate outcomes (see page 20). At the same time, policymakers and the public will demand greater certainty so that they can plan accordingly. The climate research community recognizes this problem. Now it must make a priority of addressing it.

OLIVE HEFFERNAN, EDITOR

Published online: 02 February 2010 doi:10.1038/climate.2010.11
RESEARCH HIGHLIGHTS

13 Policy

Developing need

Anna Armstrong

Paleoclimate

Insights from earth

Alicia Newton

Cryosphere

The bottom line

Olive Heffernan

Ocean science

More acid, less iron

Richard Van Noorden

14 Climate prediction

Don't count on it

Harvey Leifert

Extreme events

Strengthened storms

Alicia Newton

NEWS FEATURE

15 The road from Copenhagen: the experts' views

Olive Heffernan

\section{COMMENTARY}

18 Copenhagen number crunch

Martin Parry

20 More knowledge, less certainty

Kevin Trenberth

\section{$Q \& A$}

22 Interview: David King

Olive Heffernan 